\title{
Long and Short Term Relationship between Real Exchange Rate, Travel Revenues and Expenditure in Turkey during the Period of 2003:1-2016:1
}

\author{
Nazım ÇATALBAŞ \\ Assistant Professor, Dr., Anadolu University, Faculty of Economics and Administrative Sciences
}

\begin{abstract}
The relationship between real exchange rate and travel revenue and expenditure in Turkey, monthly data for the period of 2003:1-2016:1 by means of the VAR model have been examined in this study. Findings have been interpreted by Johansen cointegration analysis, Granger (1969) causality test, impulse response analysis and variance disintegration. Johansen cointegration test results show that there is no cointegration between data in the long term and data act randomly. Granger causality test shows that there is a causality only from real exchange rate to travel expenses in the short time. These results point out that it must be attach more importance to customer satisfaction, service quality, promotion, accessibility to destinations, security and other factors rather than real exchange rate in order to increase travel earnings of Turkey.
\end{abstract}

Keywords: Tourism, Real Exchange Rate, Cointegration Analysis, VAR, Granger Causality

\section{Introduction}

In parallel with the world welfare, especially the tourism demand is on a heavy increase. Increase in per capita income, easier transportation opportunities, global economic developments, abundance of centers, which are attractive in terms of historical, touristic and natural beauties, prices of touristic products and exchange rates are among the factors that affect the number of tourists coming to the country. Tourism demand makes travel services important. Travel (in the strict sense) services sector became a sector that is nonnegligible in terms of employment, economic growth and foreign exchange earnings.

It couldn't benefited from the tourism potential of Turkey during the last periods of 1970s, when foreign exchange bottle-neck and external debt crisis were experienced. By the foreign expansion after 1980, actions good for foreign currency have been encouraged, the tourism sector had a significant development. After the law for the encouragement of tourism enacted in 1983, tourism earnings have started to increase rapidly. Employment and production growth have been ensured in tourism-related sectors. Turkey tried to narrow the foreign trade deficit increased rapidly after the mid-1980s with earnings obtained from tourism (travel) services. In countries experiencing problems in the balance of payments (balance sheet) such as Turkey, tourism earnings had an important share in improving the payment balance, narrowing the foreign trade deficits, reducing unemployment by providing foreign currency inflow.

Tourism is the service export. Service export in travel services in particular in tourism is realized as consumption abroad. An individual (tourist) demanding international tourism travels abroad, comes to the place where tourism services are provided, and the consumption occurs. Exchange rate is an important variable for tourism as in every international action. Actions in tourism sector often occur based on foreign currency, so a change in exchange rate poses a high risk and higher volatility requires to be protected against this risk (Kutukiz, 2005:199). In this study, considering monthly data of the period of 2003:1-2016:1, whether there is a relationship between real exchange rate, tourism earnings (exports) and tourism expenses (imports) in Turkey is examined.

\section{Literature}

In literature, different results have been obtained in studies for whether there is a relationship between exchange rate, tourism earnings and tourism expenses in tourism sector. Both country difference and period difference have been key determinants in the difference of findings. The scope of the study is also very important. Tourists come from different countries to a country and while exchange rate is important for some countries, service quality and other economic and social factors come into prominence for some. Even for tourists coming from the same country in different periods, different results can be obtained. If tourists coming in autumn and spring are generally from low-earning class, changes in exchange rate can affect these persons' expenditures, so exchange rate may have an impact on the tourism demand. Some studies in the literature have been mentioned in the following paragraphs.

Dritsakis (2004) examined the relationships between real gross domestic product, real effective exchange rate and international tourism earnings of Greece in the period of 1960:1-2000:IV by using causality analysis and cointegration analysis. These have been found in the study that there is a cointegrated vector between three variables, a strong Granger causality relationship between international tourism earnings and economic growth, a strong causality relationship between real exchange rate and economic growth and a simple causality relationship between real exchange rate and international tourism earnings.

Gunduz and Hatemi-J (2005) have examined the impact of the tourism sector on the economic growth and reached findings supporting the tourism-related economic growth. 


\section{International Journal of Science and Research (IJSR) \\ ISSN (Online): 2319-7064 \\ Index Copernicus Value (2013): 6.14 | Impact Factor (2015): 6.391}

Bhattacharya and Narayan (2006) stated in the study on India after emphasizing that tourism earnings of the country increased rapidly after economic deregulation that external shocks have no lasting impact on the number of tourists coming to the country, these shocks are short-term, so their effects will be temporary and short-term.

Brida et al (2008) stated in the study on Mexico that the tourism demand of Mexico is substantially USA-based.The relationships between tourism demand and public investments, relative prices of tourist products and per capita income in the USA have been determined by Johansen cointegration analysis and time-series analysis. Additionally, a finding of one-way causality relationship from the number of tourists to relative prices has been reached in Granger causality analysis. Accordingly, in the long term, tourism demand has a positive impact on relative prices (Brida, 2008:79)

Lee and Chang (2008) examined the relationship between tourism and economic growth and co-movements in OECD and non-OECD countries. In the study, a cointegration has been found between gross domestic product (GDP) and the development of tourism on the global scale. These have been found additionally that real effective exchange rate significantly affects the economic growth, a one-way causality relationship in OECD countries from the development of tourism to the economic growth, and a twoway causality between two variables in non-OECD countries.

Narayan (2008) has found in his study on the tourism demand from 28 countries to Australia that shocks are temporary, structural breaks such as Asian crisis and September 11 terrorist attacks slowed down the increase on the number of tourists coming to the country.

Balaguer and Cantavella-Jordá (2010) has reached the solution in the study on Spain that the presence of comparative advantages in the tourism sector increase the country's foreign exchange earnings.

Uğuz and Topbaş (2011) by using monthly data of the period of 1990-2010, examined the relationship between the tourism demand and exchange rates considering the number of tourists came to Turkey and exchange rates. According to the results of the cointegration test, there is a long-term relationship between the variables. It has been found that exchange rate and exchange rate volatility affect tourism.

Kasimati and Vagionis (2012) in the study on Greece examined the relationship between tourism earnings, real exchange rate and economic growth by using annual data of the period of 1988-2010. As a result, a cointegrated relationship between three variables has been found and the result has been reached according to the results of cointegration and granger causality tests that there is no balanced relationship between economic growth and tourism earnings in the long-term.

Kara et al. (2012) in the study on Turkey, examined the relationship of tourism earnings with various macroeconomic indicators by using monthly data of the period of 1992:1-2011:5. As a result of Granger causality analysis, a one-way causality relationship from economic growth to tourism earnings, a two-way causality from tourism earnings to current account balance and a one-way causality from exchange rate to tourism earnings have been found. Accordingly, changes in the exchange rate don't affect tourism earnings.

Cheng et al (2012) in the study on USA examined the effects of quarter-monthly data of the period of 1973-2010 and real exchange rate on tourism earnings and expenditures. Depreciation of the US dollar increases the tourism demand due to the elasticity of prices in the USA and also increases tourism earnings. Depreciation of the US dollar doesn't affect the tourism imports (expenditures, costs) of the USA due to the inelastic tourism demand of countries outside of the USA.

Erkan et al. (2013) examined the determinants of tourism earnings of Turkey by using data of the period of 20052012. According to the causality results of VAR and Granger, these have been found that there is a two-way causality relationship between tourism earnings and the number of tourists, on the other hand, real exchange rate has no impact on tourism earnings.

Demirel et al. (2013) examined the effect of exchange rate on the number of tourists coming from Germany, France, UK and USA to Turkey. It has been specified that especially the service quality and tourist satisfaction (customer satisfaction) affect the number of tourists positively. Changes in real exchange rate has a significant effect on the number of tourists coming from USA to Turkey. The finding that the changes in real exchange rate have no impact on the number of tourists coming from Germany to Turkey. Customer satisfaction is a more important factor for German tourists. Nominal exchange rate is an important factor for tourists coming from France and the United Kingdom. It has been seen that the uncertainty of real exchange rate in Turkey doesn't affect the number of tourists (excluding France) coming to the country. In general, it has been found that factors such as service quality, customer satisfaction affect the number of tourists coming to the country.

Murat et al. (2013) examined by data of the period of 19962012, the impacts of economic crisis in Turkey, natural disasters and terrorist incidents on the number of tourists coming from Austria, Iran and Russia. Kapetanios (2005) unit root test allowing structural breaks has been used in the study. The findings show that the said shocks (economic crisis, natural disasters and terrorist incidents) have a permanent impact on the number of tourists coming from these countries (Austria, Iran and Russia) to Turkey.

Ghartey (2013) in his study on Jamaica, examined the causality relationship between the change in tourism in the period of 1963-2008, economic growth, real exchange rate, structural changes and hurricanes. It has been found that the impacts of these changes are cointegrated. Without structural changes and hurricane effects, the increase on the number of tourists and real tourist expenditures have a positive impact on the economic growth. Economic growth causes the real exchange rate to be decreased (country's currency to 


\section{International Journal of Science and Research (IJSR) \\ ISSN (Online): 2319-7064 \\ Index Copernicus Value (2013): 6.14 | Impact Factor (2015): 6.391}

appreciate), growth in the tourism sector causes the real exchange rate to increase. Increase in the real exchange rate (depreciation of the country's currency) increases the number of tourists coming to the country and their expenditures but the effects of the increased real exchange rate on the economic growth are controversial.

Kilic and Bayar (2014) in the study on Turkey examined the relationship between the volatility on real effective exchange rate, tourism earnings and expenditures by monthly data of the period of 1994:1-2013:8. A long-term relationship between the real effective exchange rate (REER), tourism earnings and expenditures has been found in the study. Conversely, the finding has been reached that tourism earnings and expenditures are not the Granger causality of the REER in the short-term, likewise, the REER is not the Granger causality of tourism earnings and expenditures.

Falk (2015) examined the effect of exchange rates and relative prices on Swiss tourists' demands on winter tourism in Australia. Considering the data of 63 Austria ski resorts from the winter season of 2006-2007 to the winter season of 2011-2012, about 1600 panel data have been obtained. The dependent variable is the number of overnight accommodations. According to the panel error correction results, exchange rates affect the tourism demand.

Agiomirgianakis et al (2015) in the study on Iceland, examined the quarter data of the period of 1990:1-2014:4 by Autoregressive Distributed Lags (ARDL) and cointegration analysis error correction model and had the finding that the the uncertainty of exchange rate (volatility) causes the number of tourists coming to the country to decrease.

Aydin et al. (2015) examined the international tourism demand for Turkey, and a panel data analysis has been carried out for 5 most tourist originating countries within this scope.

It has been found that there is a positive and strong relationship between exchange rate and tourism demand. Ozer et al. (2015) have found by monthly data of the period of 2002:1-2014:12 that the exchange rate affects the tourism demand from the EU (15) to Turkey, this situation is true for 5 countries generating most tourists to Turkey. The exchange rate is a granger causality for tourists coming from Germany, UK and France to Turkey in the summer.

Kanca (2015) has found a Granger causality relationship from economic growth to tourism earnings in his relevant study. Şen and Şit (2015) examined the impact of the real exchange rate on tourism earnings by monthly data of the period of 2000-2012 in Turkey. Unit root tests, frequency distribution, Toda-Yamamoto and Bootstrap-based TodaYamamoto causality tests have been used in the analysis. According to the results of the causality analysis, real exchange rate has an impact on tourism earnings and this impact occurs in the long-term. Additionally, tourism earnings affects real exchange rate. Accordingly, as long as tourism earnings increase, more foreign currencies enter to the country, and real exchange rates decrease due to the increased foreign currencies. According to the analysis results, this impact can be seen in all three periods.
Türkcan (2015) in his study on Turkey examined the validity of the tourism-related growth hypothesis by quarter-monthly data of the period of 2001:1-2014:3. It has been found in the study that GDP, tourism earnings and real effective exchange rate variables are in a cointegrated relationship in the Gregory-Hansen cointegration test. A causality relationship from GDP and real effective exchange rate to tourism earnings has been found in the Toda-Yamamoto Causality Test. It has been concluded in the study that the tourism-related growth hypothesis is not valid for Turkey.

Selim et al. (2015) in the study on Turkey examined the relationship between annual tourism earnings, the number of tourists, real effective exchange rate and GDP by data of the period of 1980-2010. According to the cointegration analysis, a long-term relationship between tourism earnings, GDP, the number of tourists and real effective exchange rate has been found. A one-way causality relationship has been identified from real effective exchange rate to tourism earning in the Block Granger Causality Test. Additionally, a causality relationship from economic growth to tourism earning and real effective exchange rate, and finally a twoway causality relationship between tourism earning and the number of tourists have been found.

\section{Data and Method}

The relationship between three variables, real exchange rate (RER), total travel earnings (REV) and total travel costs (EXP) have been examined in this study. The data have been obtained from the electronic data distribution system of the Central Bank of The Turkish Republic. RER is the consumer price index $(\mathrm{CPI})$ based $(2003=100)$ real effective exchange rate. Data on travel earnings and costs as representative of tourism earnings and costs have been investigated. At first, logarithms of level values of three variables have been taken, then these series have been separated from seasonal effects (LN_RERSA, LN_EXPSA and LN_RERSA). Longterm relationship between the variables have been tested by Johansen cointegration analysis. The short-term relationship has been examined by VAR analysis, Granger causality, impulse response analysis and variance decomposition.

\subsection{Unit Root Tests}

The first thing to be done in the empirical analysis regarding the time series is to test that the series are stationary or not. Augmented Dickey-Fuller Test (ADF) and KPSS (Kwiatkowski, Phillips, Schmidt, Shin) unit root test have been used to test the stability of the variables. KPSS (1992) ADF and Phillips-Perron are the opposites of unit root tests. Results of KPSS crosscheck ADF and PP tests, so ADF and KPSS have been preferred for the unit root test. The equation no. (1) is used for the ADF stability testing.

$$
\Delta \mathrm{Y}_{\mathrm{t}}=\beta_{0}+\beta_{1} \mathrm{t}+\delta \mathrm{Y}_{\mathrm{t}-1}+\sum_{\mathrm{i}=1}^{\mathrm{m}} \alpha_{\mathrm{i}} \Delta \mathrm{Y}_{\mathrm{t}-\mathrm{i}}+\mathrm{u}_{\mathrm{t}}
$$

It's checked in the equation no. (1) that $\delta=0$ is valid for the stability. ADF's hypotheses;

$\mathrm{H}_{0}: \delta=0(\rho=1)$ the series are not stationary.

$\mathrm{H}_{1}: \delta<0(\rho<1)$ the series are stationary. 


\section{International Journal of Science and Research (IJSR) \\ ISSN (Online): 2319-7064 \\ Index Copernicus Value (2013): 6.14 | Impact Factor (2015): 6.391}

In the event that the Null $\left(\mathrm{H}_{0}\right)$ hypothesis is rejected ( $\mathrm{H}_{1}$ accepted), it's understood that the series are stationary.(m) shows the optimal lag in the equation no. (1). Information criteria such as Akaike (AIC) and Schwarz (SC) are used to determine the appropriate lag. If other data were used in the study, 14 delays are tested for the appreciate lag. If the ADF-t statistic obtained as a result of the study is absolutely greater than the MacKinnon (1990) critical value, the null hypothesis is rejected. In the event that the series are not stationary in the ADF test, stability is examined in the first differences of the series.

Hypotheses in the KPSS unit root test are different from the hypotheses in the ADF unit root test. In the KPSS test, it's tested that the error term's $\left(u_{t}\right)$ variance $\left(\sigma^{2}\right)$ is equal to null or not. The null (zero) hypothesis $\left(\mathrm{H}_{0}\right)$ means that the series are stationary and the alternative $\left(\mathrm{H}_{1}\right)$ hypothesis means that the serial is not stationary and contains unit root. Stability in the null hypothesis shows a basic trend stability. Serials are separated from the trend and the unit root is removed.

Hypotheses of the KPSS test;

$\mathrm{H}_{0}: \sigma^{2}=0$, the series are stationary

$\mathrm{H}_{1}: \sigma^{2} \neq 0$ the series are not stationary

If the calculated test statistics is smaller than the critical value, the series are stationary $\left(\mathrm{H}_{0}\right.$ accepted $)$.

\subsection{Johansen Cointegration Analysis}

The base of the Johansen approach $(1985,1995)$ is to internally accept all variables in the model and no need to select variables for normalization. In the Johansen approach, if a model has more than two variables, it's possible that there are multiple cointegrative vectors. If the number of variables in the model is $\mathrm{n}$, cointegration number (cointegrative vectors) can be a maximum of $n-1$. If the number of cointegrations not same as the number of variables, it means there is no cointegration between these series. Therefore, series are acting randomly.

Johansen approach is indicated as follows by considering a p. Degree autoregressive process:

$$
\mathrm{Y}_{\mathrm{t}}=\mathrm{A}_{1} \mathrm{Y}_{\mathrm{t}-1}+\cdots+\mathrm{A}_{\mathrm{p}} \mathrm{Y}_{\mathrm{t}-\mathrm{p}}+\mathrm{BX}_{\mathrm{t}}+\varepsilon_{\mathrm{t}}
$$

$Y_{t}$ represents a $k$ vector of nonstationary $\mathrm{I}(1)$ variables on the level, $X_{t}$ represents a $d$ vector of deterministicvariables, $\varepsilon_{\mathrm{t}}$ represents an innovation vector in the equation no. (2).

When the first difference of the vector auto regression process of the equation no. (2) is taken, it can be shown as follows;

$$
\Delta \mathrm{Y}_{\mathrm{t}}=\pi \mathrm{Y}_{\mathrm{t}-1}+\sum_{\mathrm{i}=1}^{\mathrm{p}-1} \tau \Delta \mathrm{Y}_{\mathrm{t}-\mathrm{i}}+\mathrm{BX}_{\mathrm{t}}+\varepsilon_{\mathrm{t}}
$$

$\pi$ is the matrix of the coefficients in the equation no. (3). Rank of the matrix of the coefficients informs about the number of cointegration vectors within the equation system. (Sevüktekin and Çınar, 2014, 587-589).

In the Johansen approach, Tmatrix is estimated from a unlimited VAR and the validity of the indicated conditions is tested by the reduced rank of $\pi$. $\pi$ matrix's rank can be calculated by the trace statistic $\left(\lambda_{\text {trace }}\right)$ or Max Eigenvalue $\left(\lambda_{\max }\right)$ statistic. Test statistics obtained from $\lambda$ andmmatrices are compared with table values of Johansen-Juselius (1990) or Osterwald-Lenum (1992) (Tar1, 2012: 428).

Johansen cointegration hypotheses are as follows:

$\mathrm{H}_{0}: \tau=0$ (no cointegration) $\mathrm{H}_{1}: \tau=1$ (cointegration)

$\mathrm{H}_{0}: \tau \leq 1$ (no cointegration) $\mathrm{H}_{1}: \tau=2$ (cointegration)

$\mathrm{H}_{0}: \tau \leq 2$ (no cointegration) $\mathrm{H}_{1}: \tau=3$ (cointegration)

It has been examined by the cointegration analysis that if there is a long-run equilibrium relationship between the series. If there is no cointegration or there are cointegrations as same as the number of variables, it's considered that there is not a long-run equilibrium relationship between the variables.

The vector auto regression (VAR) model developed by Sims (1980) has been used to determine the relationship between the variables after the cointegration analysis. Variables should be stationary in the VAR analysis. In the event that the variables are not stationary on their level values, the variables' difference is taken and they are made stationary. It causes loss of data.

VAR models are simple, multi-dimensional time series forecasting model that contain delayed values of other variables in the model and values of each endogenous variable in an equation system. VAR is a forecasting model, but it allows for structural analysis (Sevüktekin and Çınar, 2014: 495; Tar1, 2010, 452). Because, each variable contains $\mathrm{p}$ delayed variables, so it increases the possibility of multi linear connection problem. Therefore, interpreting a model containing $\mathrm{p}$ delays is not meaningful.

Purpose of the VAR analysis is to demonstrate the interaction between variables, not to determine the parameter estimations (Enders, 2004:270). Therefore, the use of VAR models in econometrics is for pre-reporting for the future in this regard rather than determining a policy. Parameter estimations are made according to the results of variance decomposition and impulse-response analysis.

A VAR equation, in the most basic form, has $\mathrm{K}$ internal variables as $\mathrm{yt}=(\mathrm{y} 1 \mathrm{t}, \ldots, \mathrm{ykt}, \ldots, \mathrm{yKt})$ as $(\mathrm{k}=1, \ldots \mathrm{K})$. A VAR model for $\mathrm{k}$ of variables;

$$
y_{t}=c+A_{1} y_{t-1}+A_{2} y_{t-2}+\cdots+A_{p} y_{t-p}+\varepsilon_{t}
$$

In the equation no. (4), $\mathrm{y}_{\mathrm{t}}$ is the variable vector with a dimension of $(\mathrm{k} \times 1)$, cis the constant terms vector with a dimension of $(\mathrm{k} \times 1), \varepsilon_{\mathrm{t}}$ is the random error vector with the dimension of $(\mathrm{k} \times 1)$ and $\mathrm{A}_{\mathrm{i}}$ is the parameter matrix with the dimension of $(\mathrm{k} \mathrm{x} \mathrm{k})$. According to the VAR model, current value of dependent variable depends on random error terms $\left(\varepsilon_{t}\right)$ representing the impacts of shocks caused by factors outside the modelas well as its own and other descriptor variables' delayed values.

Causality test has a great importance on the sorting of variables in the VAR modelling. Presence and direction of the interaction between variables is determined by the Granger (1969) causality test. This test doesn't contain dependent and independent variables. Variables' interaction with each other can be simultaneously analyzed. Correct determination of lag is very important in the causality analysis 


\section{International Journal of Science and Research (IJSR) \\ ISSN (Online): 2319-7064}

Index Copernicus Value (2013): 6.14 | Impact Factor (2015): 6.391

$$
\begin{aligned}
& X_{t}=\sum_{i=1}^{m} \alpha_{i} X_{t-i}+\sum_{i=2}^{m} \beta_{1} Y_{t-i}+u_{t} \\
& Y_{t}=\sum_{i=1}^{m} \theta_{i} Y_{t-i}+\sum_{i=2}^{m} \gamma_{1} X_{t-i}+u_{t}
\end{aligned}
$$

If the addition of delayed (past) values of $Y$ to the estimation of $\mathrm{X}$ in the equation no. (5) increases the estimated performance of $\mathrm{X}, \mathrm{Y}$ is a cause of $\mathrm{X}$. In other words, $\mathrm{Y}$ affects $X$. Hypotheses for causality;

$\mathrm{H}_{0}: \beta_{\mathrm{i}}=0$ No causality relationship from $\mathrm{Y}$ to $\mathrm{X}$.

$\mathrm{H}_{1}: \beta_{\mathrm{i}} \neq 0$ Causality relationship from $\mathrm{Y}$ to $\mathrm{X}$.

In the equation no. (5), it's examined that the $\beta_{\mathrm{i}}$ coefficient is equal to zero. If it's found that the $\beta_{\mathrm{i}}$ coefficient is different than zero at a certain significance level, it's found that $Y$ is a cause of $X$.

Autocorrelation is reviewed if the VAR model has a structural problem. It's examined by searching autocorrelation in series that the error term is affected from its predecessor error terms. In the following model, if $\rho=0$, the current error term is affected from the error term of the previous period.

$$
\begin{gathered}
\mathrm{u}_{\mathrm{t}}=\rho \mathrm{u}_{\mathrm{t}-1}+\mathrm{e}_{\mathrm{t}} A R(1) \\
\mathrm{u}_{\mathrm{t}}=\rho \mathrm{u}_{\mathrm{t}-1}+\rho_{2}+\mathrm{e}_{\mathrm{t}} A R(2) \\
\mathrm{u}_{\mathrm{t}}=\rho_{1} \mathrm{u}_{\mathrm{t}-1}+\rho_{2} \mathrm{u}_{\mathrm{t}-2}+\cdots \rho_{\mathrm{k}} \mathrm{u}_{\mathrm{t}-\mathrm{k}}+\mathrm{e}_{\mathrm{t}} A R(k)
\end{gathered}
$$

Hypotheses for autocorrelation;

$\mathrm{H}_{0}: \rho=0$ No autocorrelation problem.

$\mathrm{H}_{1}: \rho \neq 0$ There is autocorrelation problem.
If there is autocorrelation in level values, difference of the series is taken and the autocorrelation problem is resolved. The reason of changes in any variable is tried to be determined by the variance decomposition. Variance decomposition shows the change in one of the internal variables as respective shocks affecting all internal variables. So, the variance decomposition informs the researcher about the dynamic structure of the system (Kosova, 2011: 116117). In each delay, the amount of delays arising from the variable or other variables is expressed by percentage (\%).

The impact of a standard deviation shock to be occurred in a variable is analyzed by the impulse-response analysis. Results of the impulse-response analysis are important indicators for policymakers. They show the results of measures to be taken in the foreign trade. The representation of the moving average vector (VMA) allows that the time route of the impacts of shocks on variables in the VAR system can be plotted in the Sims (1980) method (Barış1k and Kesikoğlu, 2006: 69-70).

\section{Empirical Findings}

Considering the results of ADF and KPSS unit root tests, level values of the series are not stationary. Therefore, first difference of the series is taken and the series became

\begin{tabular}{|c|c|c|c|c|c|c|c|c|c|}
\hline \multirow[t]{2}{*}{ Variables } & \multirow[t]{2}{*}{ Prob. } & \multirow{2}{*}{$\begin{array}{c}\text { ADF Test } \\
\text { Statistics }\end{array}$} & \multicolumn{3}{|c|}{ Critical Values } & \multirow[t]{2}{*}{ LM- Stat } & \multicolumn{3}{|c|}{ Critical Values } \\
\hline & & & $\% 1$ & $\% 5$ & $\% 10$ & & $\% 1$ & $\% 5$ & $\% 10$ \\
\hline LN_REVSA & 0.314 & $-2.526(12)$ & -4.023 & -3.441 & -3.145 & 0.199 [7] & 0.216 & 0.146 & 0.119 \\
\hline$\Delta \mathrm{LN}$ REVSA & 0.004 & $-3.717 *(3)$ & -3.476 & -2.881 & -2.577 & $0.264 *[21]$ & 0.739 & 0.463 & 0.347 \\
\hline LN_EXPSA & 0.283 & $-1.883(12)$ & -4.023 & -3.441 & -3.145 & $0.272[6]$ & 0.216 & 0.146 & 0.119 \\
\hline$\Delta \mathrm{LN}$ EXPSA & 0.003 & $-3.793 *(2)$ & -3.476 & -2.881 & -2.577 & $0.212 *[26]$ & 0.739 & 0.463 & 0.347 \\
\hline LN RERSA & 0.055 & $-3.396(2)$ & -4.018 & -3.439 & -3.143 & 0.308 [9] & 0.216 & 146 & 0.119 \\
\hline$\Delta \mathrm{LN}$ _RERSA & 0.000 & $-9.523 *(1)$ & -3.473 & -2.880 & -2.576 & $0.225 *[6]$ & 0.739 & 0.463 & 0.347 \\
\hline
\end{tabular}
stationary I(1) in the first difference (Table 1). The variables have no series $\mathrm{I}(1)$, so Johansen cointegration analysis has been performed to prevent spurious regression.

Table1: ADF and KPSS Unit Root Tests

Note: Models with constant term and trend have been used for level values and models with constant term have been used for first differences. Values in bracket (...) show Akaike information criteria-based (AIC) lag, values in square brackets [...] show the bandwidth determined by using Newey-West criterion. $* \% 1$ means the stability at significance level.

\subsection{Johansen Cointegration Analysis}

Appropriate lag has been determined as the first step in the Johansen method. Monthly data have been used, therefore an appropriate lag has been examined up to 14 periods, and it has been found that the appropriate lag is 13 . One minus appropriate lag (12) has been considered in the analysis. When the results of the cointegration analysis have been analyzed, these have been found that there is no long-term relationship between real exchange rate (RER), travel earnings (REV) and travel expenditures. Accordingly, H0 hypothesis specified that there is no cointegration relationship between the variables has been rejected. As can be seen on Table XX1, trace statistics and Max-Eigen statistics are smaller than the critical value at the 0.05 significance level.

Table 2: Selected $(0.05$ level*) Number of CointegratingRelationsby Model

\begin{tabular}{|c|c|c|c|c|c|}
\hline $\begin{array}{c}\text { Data } \\
\text { Trend }\end{array}$ & None & None & Linear & Linear & Quadratic \\
\hline $\begin{array}{c}\text { Test } \\
\text { Type }\end{array}$ & $\begin{array}{c}\text { No } \\
\text { Intercept } \\
\text { No Trend }\end{array}$ & $\begin{array}{c}\text { Intercept } \\
\text { No Trend }\end{array}$ & $\begin{array}{c}\text { Intercept } \\
\text { No Trend }\end{array}$ & $\begin{array}{c}\text { Intercept } \\
\text { Trend }\end{array}$ & $\begin{array}{c}\text { Intercept } \\
\text { Trend }\end{array}$ \\
\hline Trace & 0 & 0 & 0 & $\mathbf{0}$ & 0 \\
\hline Max-Eig & 0 & 0 & 0 & $\mathbf{0}$ & 0 \\
\hline
\end{tabular}

* Critical valuesbased on MacKinnon-Haug-Michelis (1999) 


\section{International Journal of Science and Research (IJSR) \\ ISSN (Online): 2319-7064}

Index Copernicus Value (2013): 6.14 | Impact Factor (2015): 6.391

Table 3:JohansenCointegrationTest'sResults

\begin{tabular}{|l|l|l|l|l|l|}
\hline \multicolumn{7}{|c|}{ UnrestrictedCointegrationRank Test (Trace) } \\
\hline \multicolumn{2}{|c|}{ Hypotheses } & Eigenvalue & TraceStatistics $\left(\lambda_{\text {trace }}\right)$ & Critical Values $(0.05)$ & Prob. ${ }^{* *}$ \\
\hline $\mathrm{H}_{0}: \tau=0$ & $\mathrm{H}_{1}: \tau=1$ & 0.106901 & 30.96132 & 42.91525 & 0.4462 \\
\hline $\mathrm{H}_{0}: \tau \leq 1$ & $\mathrm{H}_{1}: \tau=2$ & 0.058155 & 14.79412 & 25.87211 & 0.5917 \\
\hline $\mathrm{H}_{0}: \tau \leq 2$ & $\mathrm{H}_{1}: \tau=3$ & 0.042607 & 6.226368 & 12.51798 & 0.4321 \\
\hline \multicolumn{7}{|c|}{ UnrestrictedCointegrationRank Test $($ Max. Eigen) } \\
\hline \multicolumn{7}{|c|}{ Hypotheses } & Eigenvalue & Max-EigenStatistics $\left(\lambda_{\max }\right)$ & Critical Values $(0.05)$ & Prob. $^{* *}$ \\
\hline $\mathrm{H}_{0}: \tau=0$ & $\mathrm{H}_{1}: \tau=1$ & 0.106901 & 16.16720 & 25.82321 & 0.5298 \\
\hline $\mathrm{H}_{0}: \tau \leq 1$ & $\mathrm{H}_{1}: \tau=2$ & 0.058155 & 8.56752 & 19.38704 & 0.7680 \\
\hline $\mathrm{H}_{0}: \tau \leq 2$ & $\mathrm{H}_{1}: \tau=3$ & 0.042607 & 6.226368 & 12.51798 & 0.4321 \\
\hline
\end{tabular}

Test of TraceandMax. Eigenvalueindicatesnocointegration at the 0.05 level.

* denotesrejection of thehypothesis at the 0.05 level.

** MacKinnon-Haug-Michelis (1999) p-values

\subsection{Block Granger Causality Test}

According to the findings of the Block Granger causality test (block externalities test), there is a one-way causality relationship from real exchange rate (DF_LN_RERSAor $\triangle$ LN_RERSA) to travel expenditures (DF_LN_EXPSAor $\left.\triangle L N \_E X P S A\right)$. Accordingly, tourism demand of the citizens of Turkish Republic increases considering Turkish Lira (TL) in real terms. The reason for this is because there are opportunities to consume more goods and services by a unit of money.

There is no causality relationship between real exchange rate and travel earnings (tourism earnings). This study shows that there are factors more important than real exchange rate in tourism demand in the period of 2003-2016.

There is no causality between real exchange rate and travel earnings, it's consistent with the conclusions reached by Demirel et al. (2013). Accordingly, exchange rate has not a significant effect on the number of tourists coming to Turkey and tourism earnings. Factors such as service quality, customer satisfaction, natural beauties, accessibility to destinations, etc. are more important for many tourists coming to Turkey.
Table 4: VAR GrangerCausality /BlockWaldTests

\begin{tabular}{|c|c|c|c|}
\hline \multicolumn{4}{|c|}{ DependentVariable: Travel Revenues (DF_LN_REVSA) } \\
\hline & Chi-sq & $\mathrm{df}$ & Prob. \\
\hline DF LN EXPSA & 18.95776 & 12 & 0.0896 \\
\hline DF LN RERSA & 13.34485 & 12 & 0.3445 \\
\hline All & 29.24813 & 24 & 0.2109 \\
\hline \multicolumn{4}{|c|}{ DependentVariable: Travel Expenditures $\left(\mathrm{DF} \_L N \_\right.$EXPSA) } \\
\hline DF LN REVSA & 7.597397 & 12 & 0.8157 \\
\hline DF LN RERSA & 21.02995 & 12 & $0.0499 *$ \\
\hline All & 29.25385 & 24 & 0.2107 \\
\hline \multicolumn{4}{|c|}{ DependentVariable: Real Exchange Rates (DF_LN_RERSA) } \\
\hline DF LN REVSA & 7.092152 & 12 & 0.8515 \\
\hline DF_LN_EXPSA & 11.56989 & 12 & 0.4808 \\
\hline All & 24.49120 & 24 & 0.4338 \\
\hline
\end{tabular}

Note: ${ }^{*} p<0.05$

\subsection{VAR Analysis}

Variables should be stationary in the VAR analysis. Because the variables are not stationary on their level values, the variables' first difference is taken and they are made stationary. The most important requirement when VAR models are established is the correct determination of lag identified by information criteria. As can be seen in Table X, the appropriate lag of LR, FPE and AIC information criteria is 12 . VAR is actually a prediction model, but it allows for structural analysis (Sevüktekin and Çınar, 2014: 495; Tarı, 2010, 452). Purpose of the VAR analysis is to demonstrate the interaction between variables, not to determine the parameter estimations (Enders, 2004:270). So, the VAR analysis won't be interpreted.

Table 5: Determination of the LagLength

\begin{tabular}{|c|c|c|c|c|c|c|}
\hline Lag & $\boldsymbol{L o g} \boldsymbol{L}$ & $\boldsymbol{L R}$ & $\boldsymbol{F P E}$ & $\boldsymbol{A I C}$ & $\boldsymbol{S C}$ & $\boldsymbol{H Q}$ \\
\hline 0 & 475.0525 & NA & $2.60 \mathrm{e}-07$ & -6.648627 & $-6.586180^{*}$ & -6.623251 \\
\hline 1 & 488.9122 & 26.93851 & $2.43 \mathrm{e}-07$ & -6.717073 & -6.467285 & -6.615569 \\
\hline 2 & 507.2780 & 34.92097 & $2.13 \mathrm{e}-07$ & -6.848986 & -6.411857 & -6.671355 \\
\hline 3 & 527.8175 & 38.18613 & $1.81 \mathrm{e}-07$ & -7.011515 & -6.387044 & $-6.757755^{*}$ \\
\hline 4 & 537.2832 & 17.19819 & $1.80 \mathrm{e}-07$ & -7.018073 & -6.206262 & -6.688186 \\
\hline 5 & 547.5369 & 18.19674 & $1.77 \mathrm{e}-07$ & -7.035731 & -6.036579 & -6.629716 \\
\hline 6 & 558.4456 & 18.89819 & $1.73 \mathrm{e}-07$ & -7.062615 & -5.876121 & -6.580472 \\
\hline 7 & 565.4707 & 11.87333 & $1.78 \mathrm{e}-07$ & -7.034799 & -5.660963 & -6.476528 \\
\hline 8 & 580.0140 & 23.96576 & $1.65 \mathrm{e}-07$ & -7.112873 & -5.551697 & -6.478475 \\
\hline 9 & 597.7187 & 28.42730 & $1.47 \mathrm{e}-07$ & -7.235475 & -5.486958 & -6.524949 \\
\hline 10 & 613.9902 & 25.43855 & $1.33 \mathrm{e}-07$ & -7.337891 & -5.402032 & -6.551236 \\
\hline 11 & 616.7460 & 4.191822 & $1.47 \mathrm{e}-07$ & -7.249943 & -5.126744 & -6.387161 \\
\hline $\mathbf{1 2}$ & $\mathbf{6 4 9 . 9 2 3 7}$ & $\mathbf{4 9 . 0 6 5 6 5 *}$ & $\mathbf{1 . 0 5 e - 0 7 *}$ & $-\mathbf{7 . 5 9 0 4 7 5} *$ & $\mathbf{- 5 . 2 7 9 9 3 4}$ & $\mathbf{- 6 . 6 5 1 5 6 5}$ \\
\hline 13 & 655.9020 & 8.588481 & $1.11 \mathrm{e}-07$ & -7.547915 & -5.050033 & -6.532877 \\
\hline 14 & 665.7264 & 13.69889 & $1.11 \mathrm{e}-07$ & -7.559527 & -4.874304 & -6.468361 \\
\hline
\end{tabular}

Volume 5 Issue 4, April 2016 


\section{International Journal of Science and Research (IJSR) \\ ISSN (Online): 2319-7064 \\ Index Copernicus Value (2013): 6.14 | Impact Factor (2015): 6.391}

* indicates lag order selected by the criterion

LR: sequential modified LR test statistic (each test at 5\%level), FPE: Final Prediction error, AIC:Akaike information criterion, SC: Schwarz information criterion, HQ:Hannan-Quinn information criterion.

Table 6: VAR Estimates

\begin{tabular}{|c|c|c|c|}
\hline & \begin{tabular}{|l|}
$D F \_L N \_R E V$ \\
$S A$
\end{tabular} & $\begin{array}{l}D F_{-} L N_{-} E X P \\
S A\end{array}$ & $\begin{array}{l}D F \_L N \_R E R \\
S A\end{array}$ \\
\hline $\begin{array}{l}\text { DF_LN_REVS } \\
\text { A }(-1)\end{array}$ & $\begin{array}{l}-0.149275 \\
(-1.61956)\end{array}$ & $\begin{array}{r}0.072550 \\
(0.41192)\end{array}$ & $\begin{array}{l}0.005705 \\
(0.17346)\end{array}$ \\
\hline $\begin{array}{l}\text { DF_LN_REVS } \\
\mathrm{A}(-2)\end{array}$ & $\begin{array}{l}-0.124488 \\
(-1.35331) \\
\end{array}$ & $\begin{array}{l}-0.157007 \\
(-0.89322) \\
\end{array}$ & $\begin{array}{l}-0.004491 \\
(-0.13681) \\
\end{array}$ \\
\hline $\begin{array}{l}\text { DF_LN_REVS } \\
\text { A }(-3)\end{array}$ & $\begin{array}{l}-0.251284 \\
(-2.98683)\end{array}$ & $\begin{array}{l}-0.094799 \\
(-0.58968)\end{array}$ & $\begin{array}{l}-0.026222 \\
(-0.87343)\end{array}$ \\
\hline $\begin{array}{l}\text { DF_LN_REVS } \\
\text { A }(-4)\end{array}$ & $\begin{array}{l}-0.095765 \\
(-1.11933)\end{array}$ & $\begin{array}{r}0.127502 \\
(0.77990)\end{array}$ & $\begin{array}{l}0.013428 \\
(0.43981)\end{array}$ \\
\hline $\begin{array}{l}\text { DF_LN_REVS } \\
\text { A }(-5)\end{array}$ & $\begin{array}{l}-0.189089 \\
(-2.23685) \\
\end{array}$ & $\begin{array}{r}0.038271 \\
(0.23692) \\
\end{array}$ & $\begin{array}{r}0.027970 \\
(0.92720) \\
\end{array}$ \\
\hline $\begin{array}{l}\text { DF_LN_REVS } \\
\text { A }(-6)\end{array}$ & $\begin{array}{l}-0.235031 \\
(-2.82080\end{array}$ & $\begin{array}{l}-0.210109 \\
(-1.31965)\end{array}$ & $\begin{array}{r}0.021224 \\
(0.71382) \\
\end{array}$ \\
\hline $\begin{array}{l}\text { DF_LN_REVS } \\
\text { A }(-7)\end{array}$ & $\begin{array}{l}-0.191977 \\
(-2.26673)\end{array}$ & $\begin{array}{l}-0.051300 \\
(-0.31698)\end{array}$ & $\begin{array}{l}0.006228 \\
(0.20606)\end{array}$ \\
\hline $\begin{array}{l}\text { DF_LN_REVS } \\
\text { A }(-8)\end{array}$ & $\begin{array}{l}-0.004854 \\
(-0.05801) \\
\end{array}$ & $\begin{array}{l}-0.123311 \\
(-0.77119) \\
\end{array}$ & $\begin{array}{l}-0.028640 \\
(-0.95912) \\
\end{array}$ \\
\hline $\begin{array}{l}\text { DF_LN_REVS } \\
\text { A (-9) }\end{array}$ & $\begin{array}{l}-0.2 \\
(-2.8 \\
\end{array}$ & $\begin{array}{l}5760 \\
777) \\
\end{array}$ & $\begin{array}{l}-0.033206 \\
(-1.15705) \\
\end{array}$ \\
\hline $\begin{array}{l}\text { DF_LN_REVS } \\
\text { A }(-10)\end{array}$ & $\begin{array}{r}-0.264269 \\
(-3.24284) \\
\end{array}$ & $\begin{array}{r}0.100542 \\
(0.64564) \\
\end{array}$ & $\begin{array}{l}-0.010368 \\
(-0.35652) \\
\end{array}$ \\
\hline $\begin{array}{l}\text { DF_LN_REVS } \\
\text { A }(-11)\end{array}$ & $\begin{array}{c}0.105981 \\
(1.24012)\end{array}$ & $\begin{array}{l}-0.061229 \\
(-0.37494)\end{array}$ & $\begin{array}{l}-0.001594 \\
(-0.05227)\end{array}$ \\
\hline $\begin{array}{l}\text { DF_LN_REVS } \\
\text { A (-12) }\end{array}$ & $\begin{array}{l}0.351955 \\
(4.34260)\end{array}$ & $\begin{array}{l}-0.090633 \\
(-0.58522)\end{array}$ & $\begin{array}{l}-0.001919 \\
(-0.06634)\end{array}$ \\
\hline $\begin{array}{l}\text { DF_LN_EXPS } \\
\text { A }(-1)\end{array}$ & $\begin{array}{l}-0.015222 \\
(-0.30407)\end{array}$ & $\begin{array}{l}-0.585542 \\
(-6.12111)\end{array}$ & $\begin{array}{l}0.003152 \\
(0.17643)\end{array}$ \\
\hline $\begin{array}{l}\text { DF_LN_EXPS } \\
\text { A }(-2)\end{array}$ & $\begin{array}{r}0.020870 \\
(0.35694) \\
\end{array}$ & $\begin{array}{l}0138 \\
3394) \\
\end{array}$ & $\begin{array}{r}0.008422 \\
(0.40366) \\
\end{array}$ \\
\hline $\begin{array}{l}\text { DF_LN_EXPS } \\
\text { A }(-3)\end{array}$ & & $\begin{array}{l}2470 \\
880)\end{array}$ & $\begin{array}{l}-0.034228 \\
(-1.60994) \\
\end{array}$ \\
\hline $\begin{array}{l}\text { DF_LN_EXPS } \\
\text { A (-4) }\end{array}$ & $\begin{array}{l}-0.066333 \\
(-1.02947)\end{array}$ & $\begin{array}{l}-0.323438 \\
(-2.62687)\end{array}$ & $\begin{array}{l}-0.028284 \\
(-1.23005)\end{array}$ \\
\hline $\begin{array}{l}\text { DF_LN_EXPS } \\
\text { A }(-5)\end{array}$ & $\begin{array}{l}538 \\
830)\end{array}$ & $\begin{array}{l}7033 \\
864)\end{array}$ & $\begin{array}{l}-0.011375 \\
(-0.48577)\end{array}$ \\
\hline $\begin{array}{l}\text { DF_LN_EXPS } \\
\text { A }(-6)\end{array}$ & $\begin{array}{l}97 \\
1)\end{array}$ & $\begin{array}{l}429 \\
574)\end{array}$ & $\begin{array}{l}-0.0 \\
(-0 .\end{array}$ \\
\hline $\begin{array}{l}\text { DF_LN_EXPS } \\
\text { A }(-7)\end{array}$ & $\begin{array}{r}0.096713 \\
(1.44691) \\
\end{array}$ & $\begin{array}{l}4256 \\
+650)\end{array}$ & $\begin{array}{r}0.004764 \\
(0.19972) \\
\end{array}$ \\
\hline $\begin{array}{l}\text { DF_LN_EXPS } \\
\text { A }(-8)\end{array}$ & $\begin{array}{r}0.093338 \\
(1.47399)\end{array}$ & $\begin{array}{l}-0.114784 \\
(-0.94860)\end{array}$ & $\begin{array}{l}0.014847 \\
(0.65703) \\
\end{array}$ \\
\hline $\begin{array}{l}\text { DF_LN_EXPS } \\
\text { A (-9) }\end{array}$ & $\begin{array}{l}-0.015503 \\
(-0.25075) \\
\end{array}$ & $\begin{array}{r}-0.068674 \\
(-0.58129) \\
\end{array}$ & $\begin{array}{r}0.009032 \\
(0.40939) \\
\end{array}$ \\
\hline $\begin{array}{l}\text { DF_LN_EXPS } \\
\text { A }(-10)\end{array}$ & $\begin{array}{l}0.108167 \\
(1.91787) \\
\end{array}$ & $\begin{array}{l}-0.140220 \\
(-1.30107) \\
\end{array}$ & $\begin{array}{r}0.008913 \\
(0.44283) \\
\end{array}$ \\
\hline $\begin{array}{l}\text { DF_LN_EXPS } \\
\text { A }(-11)\end{array}$ & $\begin{array}{l}-0.006056 \\
(-0.11200) \\
\end{array}$ & $\begin{array}{l}-0.004367 \\
(-0.04226) \\
\end{array}$ & $\begin{array}{l}-0.007892 \\
-0.40905) \\
\end{array}$ \\
\hline $\begin{array}{l}\text { DF_LN_EXPS } \\
\text { A }(-12)\end{array}$ & $\begin{array}{r}0.014643 \\
(0.31798) \\
\end{array}$ & $\begin{array}{l}0.300746 \\
(3.41769) \\
\end{array}$ & $\begin{array}{l}-0.016331 \\
(-0.99377) \\
\end{array}$ \\
\hline $\begin{array}{l}\text { DF_LN_RERS } \\
\text { A }(-1)\end{array}$ & $\begin{array}{l}-0.024635 \\
(-0.09790) \\
\end{array}$ & $\begin{array}{r}0.432331 \\
(0.89914) \\
\end{array}$ & $\begin{array}{r}0.308550 \\
(3.43619) \\
\end{array}$ \\
\hline $\begin{array}{l}\text { DF_LN_RERS } \\
\text { A }(-2)\end{array}$ & $\begin{array}{r}0.313939 \\
(1.18461)\end{array}$ & $\begin{array}{l}-0.039848 \\
(-0.07869)\end{array}$ & $\begin{array}{l}-0.259430 \\
(-2.74320)\end{array}$ \\
\hline $\begin{array}{l}\text { DF_LN_RERS } \\
\text { A }(-3)\end{array}$ & $\begin{array}{l}-0.049993 \\
(-0.18024) \\
\end{array}$ & $\begin{array}{r}0.196705 \\
(0.37112) \\
\end{array}$ & $\begin{array}{r}0.120332 \\
(1.21568) \\
\end{array}$ \\
\hline $\begin{array}{l}\text { DF_LN_RERS } \\
\text { A (-4) }\end{array}$ & $\begin{array}{r}0.578484 \\
(2.07454)\end{array}$ & $\begin{array}{l}0.025366 \\
(0.04760)\end{array}$ & $\begin{array}{l}-0.025326 \\
(-0.25451)\end{array}$ \\
\hline
\end{tabular}

\begin{tabular}{|l|r|r|r|}
\hline DF_LN_RERS & 0.054004 & 0.921029 & -0.064640 \\
A (-5) & $(0.19232)$ & $(1.71647)$ & $(-0.64507)$ \\
\hline DF_LN_RERS & -0.283380 & 1.189963 & 0.026431 \\
A (-6) & $(-1.00377)$ & $(2.20580)$ & $(0.26236)$ \\
\hline DF_LN_RERS & 0.532574 & 0.730194 & -0.011086 \\
A (-7) & $(1.84709)$ & $(1.32529)$ & $(-0.10775)$ \\
\hline DF_LN_RERS & -0.404291 & 0.609252 & -0.006407 \\
A (-8) & $(-1.38447)$ & $(1.09182)$ & $(-0.06149)$ \\
\hline DF_LN_RERS & 0.329018 & -0.927924 & 0.056590 \\
A (-9) & $(1.14758)$ & $(-1.69373)$ & $(0.55311)$ \\
\hline DF_LN_RERS & 0.037859 & 0.600282 & -0.084058 \\
A (-10) & $(0.12859)$ & $(1.06694)$ & $(-0.80003)$ \\
\hline DF_LN_RERS & 0.224060 & -0.030817 & 0.100595 \\
A (-11) & $(0.80625)$ & $\mathbf{( - 0 . 0 5 8 0 3 )}$ & $(1.01435)$ \\
\hline DF_LN_RERS & -0.214370 & 0.190414 & -0.358936 \\
A (-12) & $(-0.81619)$ & $(0.37939)$ & $\mathbf{( - 3 . 8 2 9 5 7 )}$ \\
\hline C & 0.009068 & 0.021809 & 0.000776 \\
& $(1.27450)$ & $(1.60401)$ & $(0.30561)$ \\
\hline R $^{2}$ & $\mathbf{0 . 6 4 4 7 1 8}$ & $\mathbf{0 . 6 0 1 8 6 6}$ & $\mathbf{0 . 3 7 8 3 8 6}$ \\
\hline F-statistic & $\mathbf{5 . 3 9 3 5 8 6}$ & $\mathbf{4 . 4 9 3 1 5 1}$ & $\mathbf{1 . 8 0 9 2 3 5}$ \\
\hline
\end{tabular}

Note: t-stattistics in (..)

Table 7:InverseRoots of AR CharacteristicPolynomial

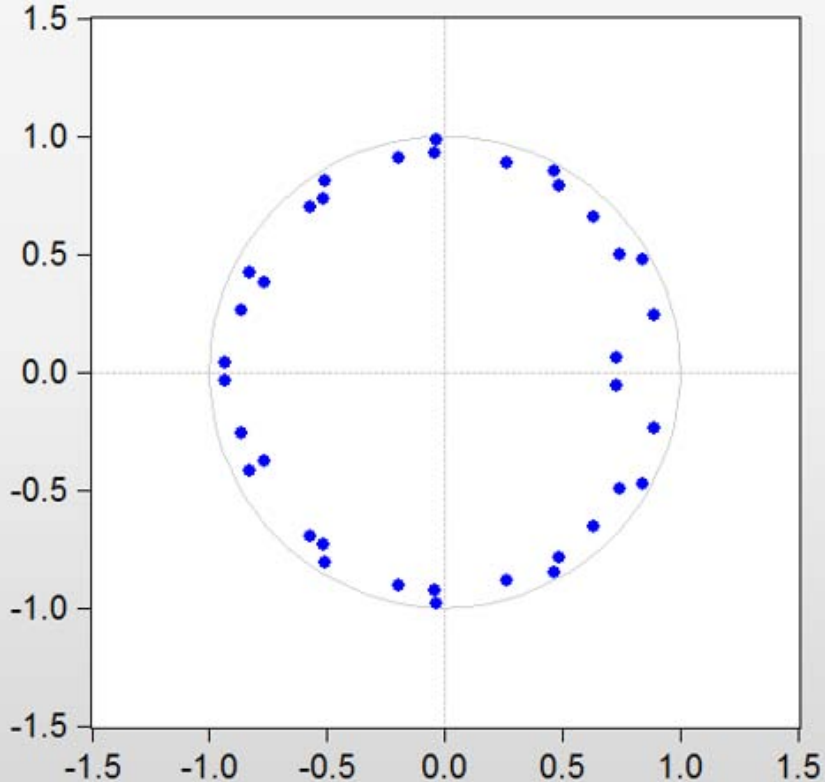

Position of the inverse roots of the AR characteristic polynomial shows that the model has no problem in terms of stability.

When the probability values in the LM test are reviewed, a LM test has been performed to determine that whether error terms in the VAR model are interrelated, in other words whether there is or not autocorrelation. In level values, there is autocorrelation in 4th and 8th lags, so difference of the series from the first degree is taken and LM has been retested. As can be seen in Table X1, probability (prob) values in series up to 8 th lag is greater than 0.05 , so there is no autocorrelation problem. 


\section{International Journal of Science and Research (IJSR) \\ ISSN (Online): 2319-7064 \\ Index Copernicus Value (2013): 6.14 | Impact Factor (2015): 6.391}

Tablo 8: VAR ResidualSerialCorrelation LM Test

\begin{tabular}{|c|c|c|}
\hline Lags & LM-Stat & Prob. \\
\hline 1 & 8.214430 & 0.5127 \\
\hline 2 & 11.94238 & 0.2166 \\
\hline 3 & 9.659688 & 0.3787 \\
\hline 4 & 15.70368 & 0.0733 \\
\hline 5 & 8.432013 & 0.4913 \\
\hline 6 & 9.525050 & 0.3903 \\
\hline 7 & 9.492907 & 0.3931 \\
\hline 8 & 17.25257 & 0.0449 \\
\hline 9 & 11.15236 & 0.2654 \\
\hline 10 & 14.60963 & 0.1022 \\
\hline 11 & 6.436538 & 0.6956 \\
\hline 12 & 5.65746 & 0.7737 \\
\hline 13 & 10.93771 & 0.2800 \\
\hline
\end{tabular}

Note:Probsfromchi-squarewith $9 \mathrm{df}$

\subsection{Impulse Response Analysis}

The reaction of each variables against its errors and other variables' errors in Graphic 1 is called as impulse-response. Impulse for the variable giving the shock, response for the variable receiving the shock are in question. As can be seen in the impulse-response analysis in Graphic 1, shock of each variable most affects first itself. Response of travel earnings against a shock in travel earnings (DF_LN_REVSA) is strong and this response is decreased in the mid-second period and fluctuates around zero. Response of travel expenditures and real exchange rate against a shock in trave earnings is very low. These responses are near the narrow band around zero after about 2 periods.

Travel expenditures have again the strongest response against a shock in travel expenditures (DF LN EXPSA). This response has negative values in mid-second period, then approaches to zero and is around zero. Responses of real exchange rate and travel earnings against a shock in travel expenditures fluctuate around zero.

Real exchange rate has again the strongest response against a shock in real exchange rate (DF LN RERSA). This response approaches to zero in mid-third period and becomes negative, then fluctuates around zero. Response of travel earnings against a shock in real exchange rate is close to zero until the first five periods. However, the decrease occurs again between 5 th and 8 th periods after the increase in travel costs. This result is consistent with the result in the causality analysis. Because, after the appreciation of the real exchange rate, tourism expenditures (foreign travel expenditures) are not directly increased, real appreciation in the exchange rate has a stability, then individuals, whose purchasing powers increased, increase their foreign tourism demands and expenditures.
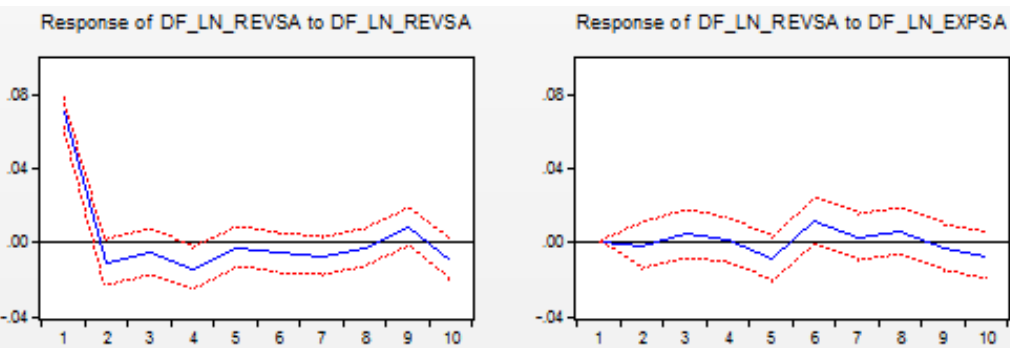

Response of DF_LN_REVSA to DF_LN_RERSA

Response of DF_LN_EXPSA to DF_LN_REVSA
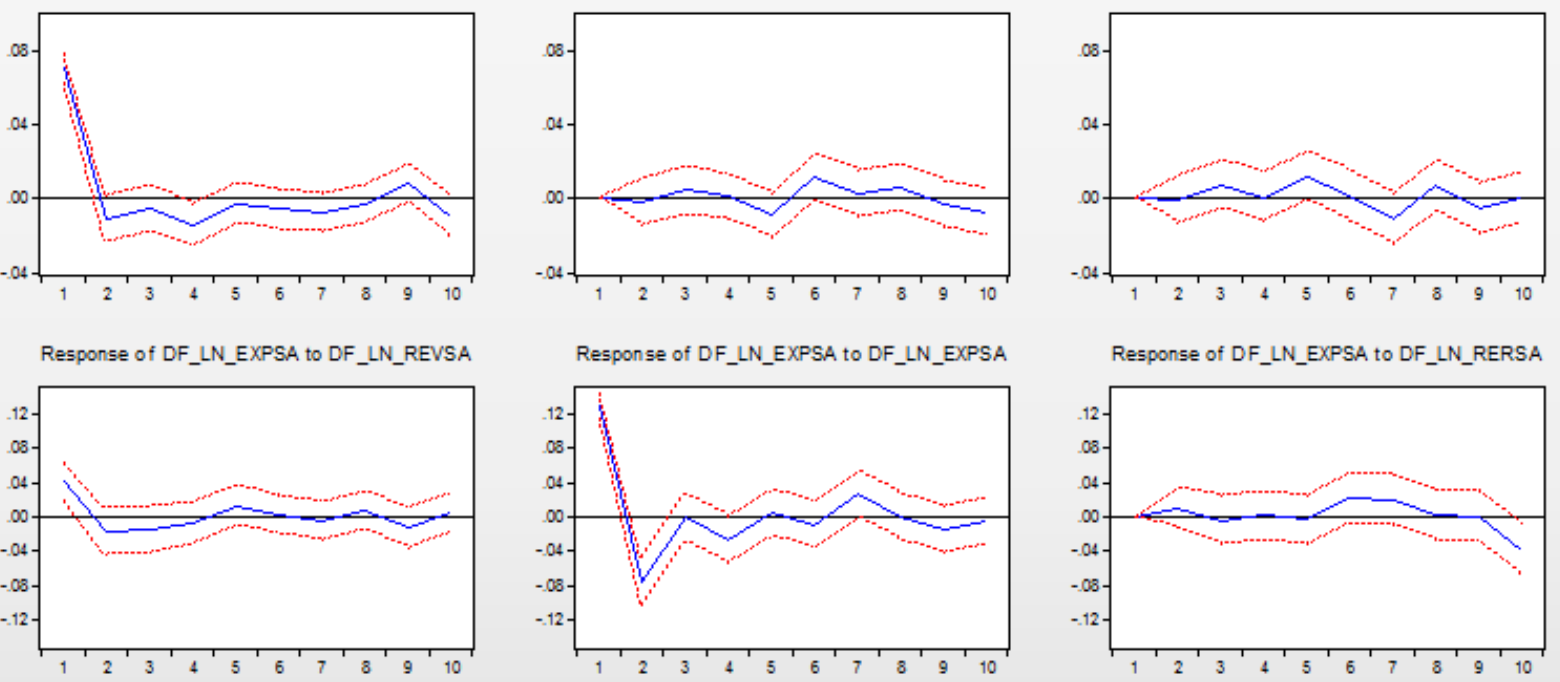

Response of DF_LN_EXPSA to DF_LN_RERSA

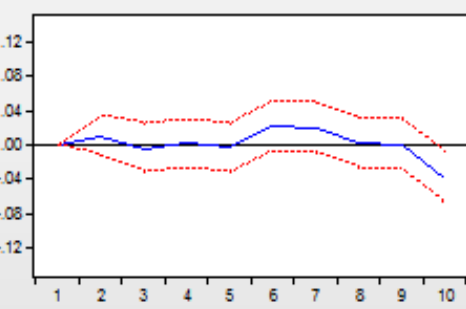

Response of DF_LN_RERSA to DF_LN_REVSA

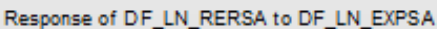

Response of DF_LN_RERSA to DF_LN_RERSA
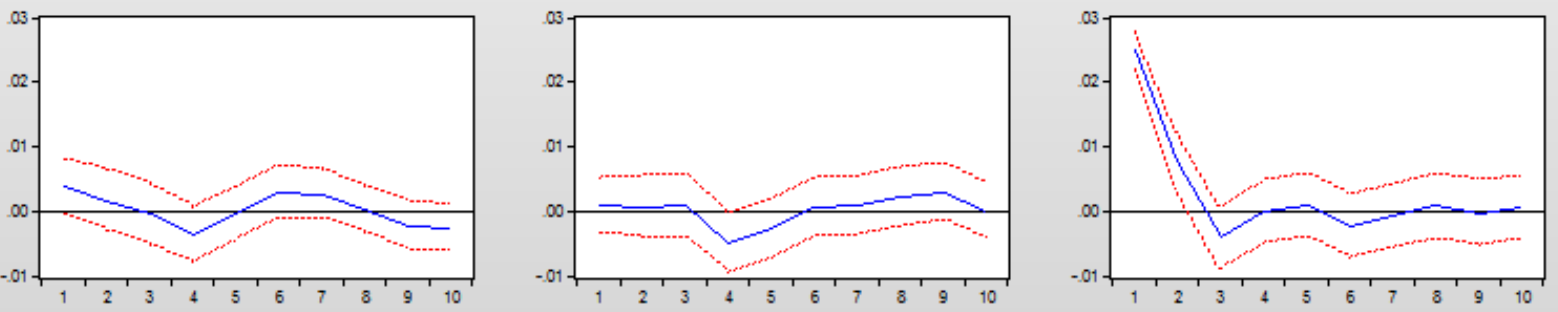

Graphic 1: Results of the Impulse-Response Analysis

Table 9 shows the results of variance decomposition. In general, dependent variables are most affected from their own shocks. Travel earnings are most affected from their own shocks $(100 \%-87 \%)$. In the first periods, the effect of real exchange rate and travel expenditures are minute amount. After that, both variables affect travel earnings at about the same rate (about 6\%). Travel expenditures are most affected from their own shocks. Secondly, they are affected from travel earnings. In the first five periods, the effect of real exchange rate on travel expenditures are minute amount. After 6th period, shocks in real exchange rates began to more affect travel expenditures. If the 


\section{International Journal of Science and Research (IJSR) \\ ISSN (Online): 2319-7064 \\ Index Copernicus Value (2013): 6.14 | Impact Factor (2015): 6.391}

continuity of the depreciation and appreciation in the exchange rate persists, the effect of real exchange rate on travel expenditures will significantly increase in the 10th period. While the power of effect of real exchange rate shocks on travel expenditures increases, effecting rate of travel expenditures from their own shocks is decreased after the 6 th period.

Real exchange rate is most affected from its own shocks. Secondly, it is affected from travel earnings and then from travel expenditures. In the first three periods, the effect of travel expenditures shocks on real exchange rate is minute amount. By 4th period, the percentage of effect of shocks of travel expenditures on real exchange rate is between $4 \%-5 \%$. The effecting rate of shocks in travel earnings (increase and decrease) on real exchange rate gradually increases. Travel earnings of Turkey are more than travel expenditures. Net surplus obtained from travel services (tourism) is very important for current account balance of Turkey. It's expected that rapid decrease or increase in tourism earnings will cause a fluctuation in nominal and real exchange rate. Travel expenditures (foreign tourism expenditures) are not higher than travel earnings, so their effect on exchange rate is limited at first. However, in the event that increases or decreases in travel expenditures persist, its power to effect the real exchange rate increases.

Tablo 9: Variance Decomposition Analysis

\begin{tabular}{|c|c|c|c|c|}
\hline \multicolumn{5}{|c|}{ Variance Decomposition of Tourism Revenues $\left(\mathrm{DF} \_L N_{-} \_\right.$REVSA) } \\
\hline Perio & S.E. & DF_LN_REVS & DF_LN_EXPS & DF_LN_RERS \\
\hline 1 & 0.07088 & 100.0000 & 0.000000 & 0.000000 \\
\hline 2 & 0.07180 & 99.91586 & 0.076779 & 0.007359 \\
\hline 3 & 0.07251 & 98.45152 & 0.446360 & 1.102116 \\
\hline 4 & 0.07395 & 98.48275 & 0.453205 & 1.064040 \\
\hline 5 & 0.07554 & 94.49939 & 1.928058 & 3.572555 \\
\hline 6 & 0.07669 & 92.25737 & 4.236877 & 3.505756 \\
\hline 8 & 0.07853 & 89.11335 & 4.814214 & 6.072431 \\
\hline 10 & 0.08029 & 87.94259 & 5.767648 & 6.289758 \\
\hline \multicolumn{5}{|c|}{ Variance Decomposition of Tourism Expenditures } \\
\hline Perio & S.E. & DF_LN_REVS & DF_LN_EXPS & DF_LN_RERS \\
\hline 1 & 0.13545 & 9.029783 & 90.97022 & 0.000000 \\
\hline 2 & 0.15626 & 7.980792 & 91.5 & 0.478600 \\
\hline 3 & 0.15709 & 8.884661 & 90.57582 & 0.539519 \\
\hline 4 & 0.15971 & 8.807485 & 90.65367 & 0.538841 \\
\hline 5 & 0.16033 & 9.369251 & 90.05335 & 0.577395 \\
\hline 6 & 0.16216 & 9.174560 & 88.37348 & 2.451962 \\
\hline 8 & 0.16592 & 9.023843 & 87.1 & 3.833629 \\
\hline 10 & 0.17164 & 9.099430 & 82.24471 & 8.655859 \\
\hline \multicolumn{5}{|c|}{ Variance Decomposition of Real Exchange Rates } \\
\hline Perio & S.E. & DF_LN_REVS & DF_LN_EXPS & DF_LN_RERS \\
\hline 1 & 0.02529 & 2.149887 & 0.138516 & 97.71160 \\
\hline 2 & 0.02650 & 2.357955 & 0.195402 & 97.446664 \\
\hline 3 & 0.02683 & 2.340739 & 0.281868 & 97.37739 \\
\hline 4 & 0.02750 & 3.920139 & 3.368007 & 92.71185 \\
\hline 5 & 0.02766 & 3.895472 & 4.340111 & 91.76442 \\
\hline 6 & 0.02792 & 4.978940 & 4.319645 & 90.70141 \\
\hline 8 & 0.02817 & 5.811217 & 4.944183 & 89.24460 \\
\hline 10 & 0.02853 & 7.058169 & 5.855651 & 87.08618 \\
\hline
\end{tabular}

\section{Results}

In this study, the relationship between real exchange rate, travel earnings and expenditures have been examined by using the VAR model and monthly data of the period of
2003:1-2016:1. The long-term relationship between the variables have been measured by Johansen cointegration analysis, short-term relationship has been measured by Granger causality test, variance decomposition and impulseresponse analysis. The most important reason to select the period of 2003-2016 is to understand that TL, which was appreciated in the period of 2002-2010 after the 2001 crisis in real terms has or has not an impact on travel (especially tourism) earnings and expenditures.

Turkey couldn't use its tourism potential until 1980s and neglected potentially perhaps one of the most important sectors that can provide foreign currency in periods when the country's economy experienced foreign currency bottleneck and external debt crisis. After 1980, by the outwardoriented strategy, it was focused on tourism investments within the incentive of foreign currency generating actions. Due to the incentives, facilities providing quality services increased, on the other hand, the importance on customer satisfaction increased, infrastructure investments make historical and touristic areas attractive increased, purchase power of foreigners increased due to the devaluation, factors such as cheap holiday opportunity and hospitality contributed foreign tourism to be developed and tourism earnings to be increased.

Tourism sector has become an important sector of Turkey in terms of current account balance. Deficit arising from the foreign trade equilibrium one of important items of current account balance is even partially closed by the surplus in service equilibrium with tourism (travel). Tourism sector, considered as smokeless industry, has an important role to meet Turkey's foreign currency obligations.

Series have been made first stationary, ADF and KPSS unit root tests have been used in this stage. Series were not stationary at level values, so their first differences were taken. Series have become stationary in the first difference and unit root was removed. Johansen cointegration test has been used to determine if there is or is not a long-term relationship between the series, it has been seen that there is no cointegrated relationship between the series. Accordingly, the series significantly act randomly in the long-term. Granger causality test have been performed to determine if there is a short-term relationship between the series and it has been determined that there is only a oneway causality relationship from real exchange rate (DF_LN_RERSA) to travel expenditures (DF_LN_EXPSA). Accordingly, appreciation of the national currency (TL) increases the tourism demand and expenditures of Turkey for abroad. Another relationship hasn't been found, it shows that especially real exchange rate has not a significant impact on tourism earnings and other areas (service quality, customer satisfaction, advertisement and promotion, infrastructure investments, etc.) should be focused to increase tourism earnings. It can be considered that TL appreciated in the period of 2002-2010, so there is no relationship between real exchange rate and travel earnings. Considering the findings reached by Demirel et al. (2013), factors such as service quality, customer satisfaction, natural beauties, accessibility to destinations, etc. are more important for many tourists coming to Turkey. 


\section{International Journal of Science and Research (IJSR) \\ ISSN (Online): 2319-7064}

Index Copernicus Value (2013): 6.14 | Impact Factor (2015): 6.391

According to the impulse-response analysis and results of variance decomposition, it can be seen that the variables most affect from their own shocks. The impact of a shock on its own applied to the variables in the impulse-response analysis decreases and approaches to zero between 2 nd and 3rd periods. After that it has values around zero. Considering the impact of variable shocks on other variables, it can be seen that the impact of a shock in the real exchange rate on travel (tourism) expenditures occurs later (after 5 periods), decreases (after 8 periods) and then approaches to zero.

Consequently, considering the one-way causality relationship between real exchange rate and travel expenditures, the increase on foreign tourism expenditures will decrease the contribution of tourism on the current account balance. On the other hand, in order to increase Turkey's tourism earnings, customer satisfaction, service quality, promotion, infrastructure services, promotion with social and sportive events, quality and accessibility rather than exchange rate, low prices should be focused. The impact of low prices and depreciation of TL in real terms on the number of tourists and tourism earning will be lower than other factors. Additionally, foreign tourism demand of Turkish citizens will be increased (decreased) by the appreciation (depreciation) of TL in real terms, therefore travel expenditures will be increased (decreased) and finally the surplus in travel services will be decreased (increased).

\section{References}

[1] Agiomirgianakis, G., D. Serenis, and N. Tsounis (2015). Effects of exchange rate volatility on touristflowsintoiceland.ProcediaEconomicsand Finance, 24, pp. 25-34.

[2] Aslan, A. (2015). Doestourismcausegrowth? EvidencefromTurkey.CurrentIssues in Tourism, DOI: 10.1080/13683500.2015.1015970.

[3] Aydın, A., B. Darıcı, and H. M. Taşçı (2015).Uluslararası turizm talebini etkileyen ekonomik faktörler: Türkiye üzerine bir uygulama.Erciyes Üniversitesi İktisadi ve İdari Bilimler Fakültesi Dergisi, 45, pp. 143-177.

[4] Balaguer, J. and M. Cantavella-Jorda (2002). Tourism as a long-runeconomicgrowthfactor: the Spanish case. AppliedEconomics, 34(7), pp. 877-884.

[5] Bhattacharya, M.,and P. K. Narayan (2006). Testingfortherandomwalkhypothesis in thecase of visitorarrivals: evidencefromIndiantourism. AppliedEconomics, 37(13), pp. 1485-1490.

[6] Brida, J.G., E. Carrera, and W.A. Risso, (2008). A longrunequilibriumdemandfunction: theMexicantourism. TOURISMOS: an International MultidisciplinaryJournal of Tourism, 3(1), pp. 66-82.

[7] Cheng, K. M., H. Kim, and H. Thompson (2013). Therealexchange rate andthebalance of trade in US tourism.International Review of Economicsand Finance, 25, pp. 122-128.

[8] Cihangir, M., B. Erkan and M. Harbalıoglu (2014). Theeffect on currentaccount of net tourismrevenues in Turkey.EuropeanScientificJournal, 10(13). pp. 47-65.

[9] Çelik Uğuz, S.,and F. Topbaş (2011).Relationshipbetweenexchange volatilityandtourismdemand:

Turkeyfortheperiod of

casestudy in Eskisehir, Turkey.

[10] Demirel, B., B. Alparslan, E.G. Bozdağ, and A.G. İnci (2013). Theimpact of exchange rate volatility on tourismsector: a casestudy, Turkey.Niğde Üniversitesi IIBF Dergisi, 6(2), pp.117-126.

[11]Dickey, D. A.,andW. A. Fuller(1979). Distribution of theestimatorsforautoregressive time serieswith a unitroot.Journal of theAmerican Statistical Association, 74(366), pp. 427-431.

[12] Dritsakis, N. (2004). Tourism as a longruneconomicgrowthfactor: an empiricalinvestigationforGreeceusingcausalityanalysis. TourismEconomics, 10(3), pp.305-316.

[13] Enders, W. (2004). AppliedEconometric Time Series. United States of America: Hamilton.

[14] Erkan, B., O. Kara, and M. Harbalıŏlu (2013). Türkiye'de turizm gelirlerinin belirleyicileri.Akademik Bakış Dergisi, 39, pp. 1-20.

[15]Falk, M. (2015). Thesensitivity of tourismdemandtoexchange rate changes: an applicationtoSwissovernightstays Austrianmountainvillagesduringthewinterseason. CurrentIssues in Tourism, 18(5), pp.465-476.

[16] Ghartey, E. E. (2013). Effects of tourism, economicgrowth, realexchange rate, structuralchangesandhurricanes in Jamaica. TourismEconomics, 19 (4), pp. 919-942.

[17] Göçer İ.,andS.Çinar (2015). Arap baharının nedenleri, uluslararası ilişkiler boyutu ve Türkiye'nin dış ticaret ve turizm gelirlerine etkileri. Kafkas Üniversitesi İktisadi ve İdari Bilimler Fakültesi Dergisi, 6(10),pp. 51-68.

[18] Granger,

$$
\text { C. }
$$

$\mathrm{W}$.

$\mathrm{J}$.

(1969). Investigatingcausalrelationsbyeconometricmodelsandcr oss-spectralmethods. Econometrica, 37(3), pp. 424-438.

[19] Gujarati, D.M. (2003). Basic Econometrics, 4th Edition, Boston: McGrawHill

[20] Gunduz, L.,and A. Hatemi-J (2005). Is thetourismledgrowthhypothesisvalidforTurkey?.AppliedEconomics Letters, 12(8), pp. 499-504.

[21] Johansen, S., (1988). Statistical analysis of cointegrationvectors. Journal of Economic Dynamics and Control, 12(2-3), pp. 231-254.

[22]__ (1995). Likelihood-BasedInference in CointegratedVectorAutoregressiveModels. New York: Oxford UniversityPress.

[23] Kanca, O. C. (2015). Turizm gelirleri ve ekonomik büyüme: Türkiye Örneği (1980-2013).TheJournal of Marmara SocialResearch, 8, pp. 1-14.

[24] Kara, O., İ. Çömlekçi and V. Kaya (2012). Turizm gelirlerinin çeşitli makro ekonomik göstergelerle ilişkisi: Türkiye örneği (1992-2011).Ekonomik ve Sosyal Araştırmalar Dergisi, 8(1), pp. 75-100.

[25] Karaatl, M. (2016). An integratedentropygrayrelationalanalysisapproach: a study on tourismindustry.Suleyman Demirel University,TheJournal of Faculty of EconomicsandAdministrativeSciences, 21 (1), pp. 6377.

[26]Kasimati, E. E.,and N. Vagionis (2012).Therelationshipbetweentouristreceipts, 


\section{International Journal of Science and Research (IJSR) \\ ISSN (Online): 2319-7064 \\ Index Copernicus Value (2013): 6.14 | Impact Factor (2015): 6.391}

realexchange rate andeconomicgrowth in Greece.2 ndAdvances in HospitalityandTourism Marketing\& Management Conference, 31st May to 3rd June,Corfu Island, Greece.

[27] Kesikoğlu, F.,and S. Barışık (2006). Türkiye bütçe açıklarının makroekonomik değişkenler üzerine etkisi (1987-2003 VAR, etki-tepki analizi, varyans ayrıştırması).Ankara Üniversitesi SBF Dergisi, 61(4),pp.59-82.

[28] Kılıç C.,and Y. Bayar (2014). Effects of realexchange rate volatility on tourismreceiptsandexpenditures in Turkey.Advances in Management \&AppliedEconomics, 4(1), pp. 89-101.

[29] Kosova, G. (2011). Ayrışma hipotezi ve yükselen piyasa ekonomilerinde ABD etkisi. Basılmamış Doktora Tezi, Kadir Has Üniversitesi Sosyal Bilimler Enstitüsü İşletme Anabilim Dalı Finans Ve Bankacılık Bilim Dalı,

[30] Kutukız, D. (2005). Turizm sektöründe döviz riski ve korunma yöntemleri. Muhasebe ve Finansman Dergisi, 28, pp. 198-207.

[31] Kwiatkowski, D., P. C. B. Phillips, P. Schmidt,and Y. Shin (1992). Testingthenullhypothesis of stationarityagainstthealternative of a unitroot.Journal of Econometrics 54(1-3), pp. 159-178.

[32]Lee, C-C., and C-P. Chang (2008). Tourismdevelopmentandeconomicgrowth: A closerlook at panels.Tourism Management, 29 (1), pp. 180-192.

[33] MacKinnon, J. G., A. A. Haug, and L. Michelis (1999). Numericaldistributionfunctions likelihoodratiotestsforcointegration. Journal of AppliedEconometrics, 14(5), pp. 563-577.

[34] Maloney, W.F., and G.V.M. Rojas (2001).DemandforTourism. New York: The World Bank.

[35] Murat, S., S. Şener, and Veli Yılancı (2013). İktisadi krizler, doğal afetler, terör faaliyetleri Türkiye'ye gelen turistler üzerinde etkili mi?.Iktisat Fakültesi Mecmuası, 63(1), pp. 1-15.

[36] Narayan, P. K. (2008). Examiningthebehaviour of visitorarrivalstoAustraliafrom 28 differentcountries.TransportationResearchPart $A$ : PolicyandPractice, 42(5), pp. 751-761.

[37] (2005).Thestructure of touristexpenditure in Fiji: evidencefromunitrootstructural break tests.AppliedEconomics, 37(10), pp. 1157-1161.

[38] Özer, M., İ. O. Coşkun, andM. Kırca (2015). Time varyingcausalitybetweenexchangeratesandtourismdema ndforTurkey. Journal of TourismResearch, 10, pp.123144.

[39] Patsouratis, V., Z. Frangouli, and G. Anastasopoulos (2005). Competition in tourismamongthemediterraneancountries. AppliedEconomics, 37(16), pp. 1865-1870

[40]Ruane, M.C.M. (2014). Exchange ratesandtourısm: evidencefromtheisland of Guam. Journal of EconomicandEconomicEducationResearch, 15(2), pp. 165-186.

[41] Selim, S., E.T. Ayvaz Güven, and P. Eryiğit (2015).Place of tourism in theTurkisheconomy: time seriesanalysis. International Journal of Alanya Faculty of Business, 7(3), pp. 19-33.

[42] Sevüktekin, M., and M. Çınar (2014). Ekonometrik Zaman Serileri Analizi. Bursa: Dora Yayınları.
[43] Sims, C.A. (1980). "MacroeconomicsandReality," Econometrica, 48(1), pp.1-48.

[44] Şen, A., and M. Şit (2015). Theempiricalanalysis of realexchange rate impact on Turkey'stourismreceipts. Journal of YasarUniversity, 10(40), pp. 6752-6762.

[45] Tarı, R. (2010). Ekonometri. Gözden Geçirilmiş 10. Bask1, Kocaeli: Umuttepe Yayınları.

[46] Türkcan, B. (2015). 2000'li yıllarda Türkiye için turizm yanlı büyüme hipotezinin analizi.Dokuz Eylül Üniversitesi İktisadi ve İdari Bilimler Fakültesi Dergisi, 30 (2), pp. 1-18.

[47] Vita, G. D. (2014). Thelong-runimpact of exchange rate regimeson internationaltourismflows.Tourism Management, 45, pp. 226-233.

[48]Zhang, G., T. Pu, and P. Zhang (2011). An empiricalstudy on therelationship of realexchange rate of

rmbandChineseinboundtourismfromAmerica.Internatio nal Conference on Management and Service Science MASS , 12-14 August, Wuhan,China, pp. 1-4. 